\title{
中国産魚醤油の化学成分
}

\author{
黑 川 孝 雄*
}

\section{Chemical Composition of Chinese Fish Sauce}

\author{
Takao KURoKaWA* \\ * Nagasaki Prefectural Institute of Fisheries, Matsugae-machi, Nagasaki, 850 \\ Present adress; Mitsushima Fisheries Extension Office for Improvement aud \\ Popularization of Nagasaki Prefectural, Ikenoura, Kusubo, Mitsushima-cho, \\ Shimoagata-gun, Nagasaki, 817-03
}

\begin{abstract}
Special, first and second grade chinese fish sauce were examined in quality in terms of chemical composition, free amino acid etc. The results were as follow: (1) Sodium chloride content and $\mathrm{pH}$ value were similar in every sample but there were significant differences in other other chemical composition. (2) Free amino acid content was higher in the first grade and less in the special grade fish sauce. In special grade sauce, leucine, alanine and glutamic acid predominated. In the first and second grade sauce, glutamic acid predominated, followed by lysine and alanine. (3) The correlation was not recognized between the sauce grade and chemical composition, free amino acid content or sensory score.
\end{abstract}

(Received Jun. 28, 1985)

魚醬油は，魚介類を高濃度の食塩と共に熟成して造る 酸酵調味料で, 東南アジア地方では重要な水産加工品の 1つに数えられている゙。. 一方，我が国でも秋田のしょ つつる, 石川のいしりなどの魚醬油が有名であるが, 生 産量は少ない2). しかし, 最近, 未利用魚や加工残椬の 有効利用の見地から魚䇴油がみな拈され，いくつかの試 作報告が成されている(3) ，また，市販黄醬油の化学成 分等については，しょっつる10) 16), フィリピン産の

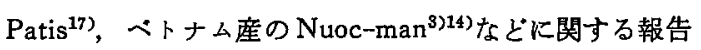
はあるか，中国産のるのについてはないようである.そ こで,この度, 著者が分析した中国福建省産魚篦油につ いて報告する.

\section{実 験 方 法}

\section{1. 試料}

用いた魚醬油は，1984 年6月18日に入手した中華人 民共和国福建省産の輸出向け特級品および国内向け 1,2 級品の各 1 種, 計 3 試料である.
なおこれらの魚醬油は，ビール瓶様のガラス容器に 約 $750 \mathrm{~g}$ 充てんされ，口部分は，プラスチック樹脂で溶 融密栓されていた.

2. 化学成分の測定

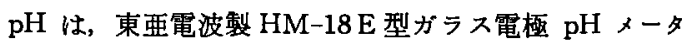

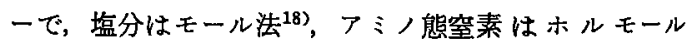
法 $^{18)}$ ，揮発性塩基態窒素 (以下, VBN と称す) およびト リメチルアミン態窒素 (以下, TMA-N と称す) はコン ウェイの微量拡散法 ${ }^{19)}$ ，䋰濁物質は Whatman GF/C 沪 紙を用いる方法 ${ }^{202}$, 遊離了ミノ酸は, 試料をクエン酸縓 衝液 (pH 2.1) で500 倍に希釈して，日本電子製 JLC200 型全自動高速アミノ酸分析機で定量した。

\section{3. 生菌数の測定}

藤井ら ${ }^{15)}$ が，魚醬油の生菌数測定に用いた 2.5 およ゙ $20 \%$ 食塩加 BPG 寒天培地 (ただ，魚肉エキスに替え て肉エキス GIBCo Beef extract Dri-form を用いた) を 使い, 平板塗抹法で $2.5 \%$ 培地は 7 日間, $20 \%$ 培地は 30 日間，それぞれ $30^{\circ} \mathrm{C} て ゙$ 培盖して計数した.

* 長崎県水産試験場（广850長崎市松ヶ枝町 7-29）

現在：長崎県美律島水産業改良普及所（T817-03 長崎県下県郡美津島町久須保池 >浦 668） 


\section{4. 色調の測定}

試料をそのままおよび基準しょうゆ分析法 ${ }^{21}$ に準し て，10\%食塩水で 10 倍に希积したものを被検液とし， 日本電色工業製 ND-503 DE 型測色色差計で測定した。

\section{5. 官能検查}

長䗁県水産試験場の研究員 7 名をバネルとして, 臭気,

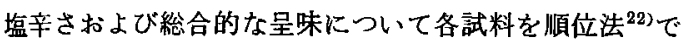
比較した.

\section{結果および考察}

\section{1. 化学成分および生菌数}

中国福建省産魚醬油の特級， 1 級および 2 級品各 1 試 料の化学成分就よび生菌数の分析結果は, Table 1 K示 す通りである.すなわち，各試料の $\mathrm{pH}$ および食塩濃度 は比較的近似しているが，その他の成分の含有量はかな り相違している. しかし，低品質の製品ほど総絰素执よ びフミノ態窒素が低い値を示したしょっつる は異なり，本試料では，等級と各化学成分の含有量との 間に一定の関係を認めることはできない。

生菌数の測定は，藤井ら ${ }^{15)}$ 方法に準じて行ったので あるが，藤井らの調べた Patis ${ }^{17)}$ やょつつる ${ }^{15)}$ の生菌 数に比ぺて著しく少ない、これは, 使用した培地の $\mathrm{pH}$ が 7.5 と本試料の pH 5.95 6.11 に比べて高いこと も一因と考えられる. しかし，藤井らが調べたしょっつ るの $\mathrm{pH}$ \& 5.97 6.04 と本試料の $\mathrm{pH}$ と大差ないるの であり，本試料の生菌数が少ないことが使用培地の $\mathrm{pH}$ のみに起因するとは考え難い，従って，詳細を知るには， ざらに検討が必要である。

次に，本試料の個々の化学成分をしょっつる 17), Nuoc-man ${ }^{3)}$ およ゙ Patis ${ }^{17)}$ についての既応の報告と
比較すると $\mathrm{pH}$ は，しょっつる 4.5〜6. 85, Patis 5.1, Nuoc-man 6.50 と試料によって相当異なっているので, 本試料の $\mathrm{pH}$ との単純比較は難しい. 大野ら ${ }^{10)}$ は, 使用 する原料や製法によってしょっつるの $\mathrm{pH}$ が相違する ことを認めておりこれらの魚跴油の $\mathrm{pH}$ が相違するの も同様の原因によるものと考えられる，また，食塩濃度 は, Patisの29.1\%とほぼ等しく，しょっつるの場合は $22.0 \%^{\mathrm{a})}$ と低い試料むあるが，多くは27〜29\% ${ }^{7313) 15) ~}$ 本試料と大差はない：これは，いずれの焦踷油の場合で も食塩は，主として熟成中の腐敗防止の目的で用いられ るのであろらから, その使用量もおのずから類似したも のになるのであろら.

本試料の絍窒素は，いずれる高濃度含まれており，最 る低い特級品でも Patis とほぼ同程度，しょっつる， Nuoc-man よりも高い, また, VBN, TMA-N む Patis, しょっつるに比べて高濃度である。

総窒素に占めるアミノ態窒素の割合は，特級，1およ び 2 級品が，それぞれ 0.30，0.36お゙よ゙0.29であり， しょっつるについて分析した大野ら ${ }^{13)}$ の $0.37 \sim 0.54$, 吉

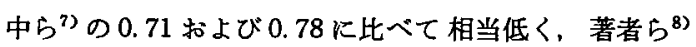
が，マイワシを $30^{\circ} \mathrm{C} て ゙ 1$ ケ間熟成して試製した魚醬 油の $0.37 \sim 0.51$ に比べても低い. 従って, 本試料には, ペプチド形態のものが多く含まれていることが推察され る.また，総室素に占める非タンパク態窒素の割合は， 特級，1および2級品が，それぞれ0.84，0.85および 0.82 で，大野ら ${ }^{13)} の 0.89 \sim 0.96$ ，著者ら ${ }^{8 /} の 0.96 \sim 1.00$ に比べて若干低めである、これは，我が国では一般に行 われる火入れ，扣り引き処理 ${ }^{23) 24}$ が，本試料では成され ていないか，あるいは不十分であることを示唆している のではなかろらか：このことは，本試料の䜿濁物質が，

Table 1 Chemical composition and microbial counts of Chinese fish sauce

\begin{tabular}{cccc}
\hline Grade & Special & First & Second \\
\hline $\mathrm{pH}$ & 6.11 & 6.00 & 5.95 \\
Nacl (\%) & 29.1 & 28.0 & 28.6 \\
Total N (mg N/100 ml) & 1459.4 & 2376.4 & 1866.6 \\
Non protein N (mg N/100 ml) & 1224.9 & 2023.0 & 1535.3 \\
Formol N (mg N/100 m $)$ & 746.8 & 1269.9 & 844.7 \\
Volatile base N (mg N/100 ml) & 314.4 & 404.6 & 296.8 \\
Trimethylamine N (mg N/100 ml) & 18.3 & 11.9 & 8.2 \\
Viable cell count (cells $/ \mathrm{m} l)$ & & & \\
$2.5 \% \mathrm{NaCl}$ medium & $5.8 \times 10$ & $3.2 \times 10^{2}$ & $4.3 \times 10$ \\
$20.0 \% \mathrm{NaCl}$ medium & $7.5 \times 10$ & $6.6 \times 10^{2}$ & $9.0 \times 10$ \\
\hline
\end{tabular}


Table 2 Free amino acid composition of Chinese fish sauce

\begin{tabular}{lrrr}
\hline & \multicolumn{3}{c}{ Grade } \\
\cline { 2 - 4 } Amino acid & Special & First & Second \\
\hline Aspartic acid & $170^{*}\left(4.0^{* *}\right)$ & $787^{*}\left(8.4^{* *}\right)$ & $603^{*}\left(8.4^{* *}\right)$ \\
Threonine & $82(1.9)$ & $444(4.7)$ & $256(3.6)$ \\
Serine & $30(0.7)$ & $130(1.4)$ & $171(2.4)$ \\
Glutamic acid & $500(11.8)$ & $1948(20.8)$ & $1333(18.6)$ \\
Proline & $53(1.2)$ & $268(2.9)$ & $236(3.3)$ \\
Glycine & $132(3.1)$ & $668(7.1)$ & $343(4.8)$ \\
Alanine & $543(12.8)$ & $1048(11.2)$ & $747(10.4)$ \\
Cystine & $269(6.3)$ & $406(4.3)$ & $401(5.6)$ \\
Valine & $419(9.8)$ & $704(7.5)$ & $567(7.9)$ \\
Methionine & $94(2.2)$ & $245(2.6)$ & $185(2.6)$ \\
Isoleucine & $321(7.5)$ & $375(4.0)$ & $328(4.6)$ \\
Leucine & $548(12.9)$ & $573(6.1)$ & $519(7.2)$ \\
Tyrosine & $38(0.9)$ & $0(0)$ & $82(1.1)$ \\
Phenylalanine & $380(8.9)$ & $368(3.9)$ & $443(6.2)$ \\
Histidine & $310(7.3)$ & $242(2.6)$ & $261(3.6)$ \\
Lysine & $365(8.9)$ & $1164(12.4)$ & $684(9.6)$ \\
Total & 254( & 9370( & 7159 \\
\hline
\end{tabular}

* $\mathrm{mg}$ amino acid $/ 100 \mathrm{~m} l$ sample

** \%

高濃度であることからる推察されることである。

\section{2. 遊離アミノ酸}

遊離了ミノ酸の組成は, Table 2 に示すごとく特級, 1 級拉よび 2 級品ともに中性了ミノ酸が最も多く，それ ぞれ 48.7，42.0 および 40.9\% 含まれている. 酸および 塩基性フミノ酸は, 特級と 1,2 級品では異なり, 前者で は，酸扎よび塩基性てミノ酸がほぼ同量の 15.8 およ゙ $16.2 \%$ であるに対して, 後者では，酸性てミノ酸が塩 基性 フミノ酸よりも多く, 1 級品では 29.2 および 15.0 \%，2級品では 27.0 执よび $13.2 \%$ 含まれている。は， 個々の遊離〉ミ，酸の量的比率をみると，特級品と 1,2 級品では若干異なる.すなわち, 前者ではロイシン, ア ラニン,グルタミン酸がはぼ同量含まれていて最も多く, 次いでペリンフェニルアラニン，リジンが近似して含 まれこれら6種のアミノ酸が全体の $65.1 \%$ 占めて いる. 一方, 後者ではダルタミン酸が，それぞれ20.8お よび $18.6 \%$ と他のアミノ酸に比べて压倒的に多く，次い でリジン，アラニン，アスパラギン酸，バリンの順に多 く含まれこれら 5 種のアミノ酸で全体のそれぞれ 60.3 和よび54.9\%を占めている。

次に，本試料の遊離フミ，酸組成を他の魚醬油のそれ
と比較すると，特級品は Patis ${ }^{17)}$ に類似しているが， ア ルギニン,トリプトファンが全く含まれていない点で, 1, 2 級品は Nuoc-man ${ }^{3}$ K類似しているが, Nuoc-man にはスレオニン, セリンが痕跡程度しか含まれていない 点でそれぞれ異なる. また，しょっつる377)13)15)とむ若干 相違している.

大野ら ${ }^{13}$ は，しょっつるの遊離了ミノ酸の総量や組成 が，使用する原料魚種によって異なり，また，同一工場 で造られたものでは，品質の上位のむのほどてミ，酸の 総量が多く、グルタミン酸、アラニンなどのアミ，酸が 多く含まれ，逆にイソロイシン，ロイシン，フェニルフ ラニンは少ない傾向を認めている. 本試料では, このよ らな等級とアミノ酸の総量との間に一定の関俰を認める ことはないものの, 個々のアミノ酸についてみるとフラ ニンの含有量は，等級の上位のむのほど多く，逆にセり ンプロリンは少ない傾向にある.しかし，その差は璜 少であり，等級差に反映しているとは考えられない。 中国の福建地方に㧍ける魚醬油の製法は，先ず石造り のタンクに原料魚とその $25 \%$ 程度の食塩を入れて約 1 年間放置して熟成ざせ，次にタンク中の内容物を戸外に 置いた陶器製のかめに移し替えて時々㩭捧しながらさら 
Table 3 Color of chinese fish sauce

\begin{tabular}{cccc}
\hline Grade & Special & First & Second \\
\hline $\mathrm{Y}$ & 43.3 & 2.5 & 1.0 \\
& $84.4^{*}$ & $36.1^{*}$ & $31.5^{*}$ \\
$\mathrm{x}$ & 0.46 & 0.59 & 0.55 \\
& $0.35^{*}$ & $0.45^{*}$ & $0.45^{*}$ \\
$\mathrm{y}$ & 0.44 & 0.38 & 0.44 \\
& $0.36^{*}$ & $0.43^{*}$ & $0.43^{*}$ \\
\hline
\end{tabular}

* sample was diluted by ten times with $10 \%$ $\mathrm{NaCl}$ solution.

に 1 年間位熟成させたのち沪過する，得られた沪液が上 級品の魚醬油であり，その沪過残椬に濃い食塩水を加え て抽出，沪過した沪液が下級品の魚醬油である.なお これらの沪液についてはそれぞれアミ，酸濃度を測定 し，一定濃度に調整する操作を加えたのち製品化するよ らである. 従って, 本試料間のアミ，酸の量, 組成など に前述のよ5な相違が羿められたのは，このよらな製法 の違いとアミ，酸濃度の調整に起因するものであろう。

\section{3. 色調および官能検查}

本試料の色調は，特級品と 1,2 級品では異なり，前者 は淡い黄赤色，後者は濃い暗赤褐色を呈している、これ らを色差計で測定し，CIE 表色法 ${ }^{25)}$ で示したのが Table 3である. 魚醬油の色調についての報告がないので，他 との比較が出来ないが，1，2 䑥品の色は，本邦産の款物 醬油に比較的類似したものである.

次に，本試料を水で 10 倍に希彩したものを被検液と して，臭気拉よび塩辛さの強弱並びに総合的な呈昧の好 みについて，各陚料を順位法で比較したところ臭気およ び塩辛さの強さは，それぞれ特級 $>1$ 級 $=2$ 級，特級 $=1$ 級 >2級，総合的な呈味の好みについては，2 級>特級 $=$ 1 級の順であった，しかし，この結果を $\mathrm{t}$ 検定 ${ }^{22}$ で検討 したところいずれの項目についても各試料間に有意の関 俰を器めることは出来なかった。

$$
\text { 要䄪 }
$$

品質等級の異なる中国福建省産魚槳油 3 種 の化 学 成 分，遊離アミノ酸などを調べて，次の結果を得た。

(1) 各試料の食塩濃度および $\mathrm{pH}$ は近似しているが, その他の化学成分の含有量はかなり相違した.すなわら, 䋰濁物質 $210 \sim 670 \mathrm{ppm}$ ，総窒素 1459 2376 mg N/100 $\mathrm{ml}$, 非タンパク態窒素 $1224 \sim 2023 \mathrm{mg} \mathrm{N} / 100 \mathrm{ml}$, ア ミ , 態空素 432 $865 \mathrm{mg} \mathrm{N} / 100 \mathrm{ml}$, VBN 296 404 mg N/ $100 \mathrm{~m} l$ および TMA-N 8～18 mg N/100 ml である.
（2）遊離フミノ酸の総量は，1 級，2 級, 特級の順に多 く，個々のアミ，酸の含有割合は，特級品ではロイシン， アラニン，グルタミン酸が汪ぼ同程度で多く含まれ，1， 2 級品ではダルタミン酸が最も多く，次いでリジン， フ ラニンが多く含まれた。

(3) 魚醬油の等級と化学成分, 遊離アミ，酸，官能検 查などとの間に一定の関係を認めることはできなかっ た.

終りに，試料の入手に当って便宜を頂いた中華人民共 和国福建省水産公司施篤強氏, 同廈門市水産公司陸会椿, 朱宗芸両氏，中国における魚䋢油の製法についてご教示 頂いた福州市水産品加工付陳国平氏並びにアミノ酸分析 をご援助下さった長崎大学薬学部教授鶴大典博士に媣謝 します。

文献

1) Van, Veen, A. G.: Advance in Food Research., 4, 209 (1968)

2) 三輪勝利：水産加工品総覧，三輪勝利監修（光琳， 東京), p. 391 (1984).

3）阿部憲治・鈴木健治・橋本周久：日水誌, 45,1013 (1979).

4) 中村秀之・毛利善治・村岡一郎 - 伊藤 克：日水 誌, 45, 1389 (1979).

5）策瀬正明：東海水研報， 108，1（1982）。

6) 三宅義章：日食工誌，29，428 (1982).

7) 吉中澧二・佐藤 守・土谷 望- 池田静徳：日水 誌, 49, 463 (1983).

8）日下部重朗・黒川孝雄・㯪木重哉：昭和 57 年度 長崎県水試事業報告, 121 (1983).

9）日下部重朗・黒川孝雄・㯪木重哉：昭和 58 年度 長崎県水試事業報告, 145 (1985).

10）大野悦子・浅野元一：秋田大教育学部紀要， 18 , 81 (1968).

11）阿部輝雄 - 露木英男：日食工誌, 15, 535 (1968).

12) 阿部輝雄 - 露木英男: 日食工誌, 16, 560 (1969).

13）大野悦子・浅野元一：秋田大教育学部紀要, 20 , 27 (1970)

14) Nonaka, J., Le, T. M. D. and Kolzumi, C.: J. Tokyo Univ. Fish., 62, 1 (1975).

15）藤井建夫・酒井久夫・日水誌，50，1061 (1984).

16）藤井建夫・酒井久夫：日水誌，50，1067 (1984).

17）藤井建夫・S. BAMBANG，B ASUKI -戸沢晴巨：日 水誌, 46, 1235 (1980).

18）日本薬学会編：衛生試験法注解，1980年版（金原 出版, 東京), p. 62 (1983)。

19）山形誠：水産生物化学・食品学実験畫, 劣藤恒 行 - 内山 均 - 梅本 滋 - 河端俊治編, (恒星社 厚生閣, 東京), p. 281 (1974). 
20）澤田保夫 - 町田喜弘：新編・水質污濁調査指針, 日本水産資源保護協会編，(恒星社厚生閣,東京), p. $136(1980)$.

21）日本醬油技術会：基準しょうゅ分析法（日本醬油 技術会，東京)，p. 17 (1966)。

22) 東京㖘工大学豊学部食糧化学教室編：食品学実験 法, (朝會書店, 東京), p. 182 (1960)。
23）藤井建夫・小沢千重子：さかな，25，10(1980),

24）山瀬 登：水産加工品総覧，三輪勝利監修，（光 琳, 東京), p. 395 (1984).

25）日本電色工業株式会社：色比関する事柄，(日本電 色工業株式会社，東京）， p. 1（1979）。

(昭和 60 年 6 月 28 日受理) 